\title{
PLASMA TECHNOLOGIES AS THE BASIS FOR THE DEVELOPMENT OF RUSSIAN WASTE PROCESSING
}

\author{
Sergey Filin ${ }^{1,}$, , Vladimir Velikorossov ${ }^{2}$, Lyubov Chaikovskaya ${ }^{1}$, Elmira Zhussipova ${ }^{2}$, Alexey Yakushev $^{1}$, and Evgeny \\ Genkin $^{1}$ \\ ${ }^{1}$ Plekhanov Russian University of Economics, Department of Management, 117997, Stremyanny Lane, 36, Moscow, Russian Federation \\ ${ }^{2}$ M.Auezov South-Kazakhstan State University, 160012, Tauke Khan Ave, Shymkent, Kazakhstan
}

\begin{abstract}
The article considers the current topic - justification of the possibility of organizing a system for recycling solid domestic and other waste based on plasma technologies and the subsequent use of secondary raw materials based on them. The current state of production sector of collection and disposal of solid domestic and other waste abroad and in Russia was analyzed. There are proposed a scheme of organization of solid domestic and other waste disposal system based on plasma technologies, operable at the under construction enterprise for processing of these wastes. The economic feasibility of this enterprise is justified. It was concluded that although the use of plasma technologies is most beneficial in the energy sector, when introducing plasma plants and creating solid waste disposal plants using these plants, taking into account the financial benefits in obtaining the raw materials and energy generated by them is not the main task, but an additional economic effect. The main thing is to reduce the negative impact of solid municipal waste on the environment and people.
\end{abstract}

\section{Introduction}

Nowadays there is an increasing number of human Human life is closely related to the permanent generation of a significant amount of solid municipal waste, which can include solid municipal waste. These are substances, their mixtures, things, municipal waste, other items human life products obtained during consumption and recognized as unsuitable for further use directly in places of consumption (for example, discarded by the consumer due to unnecessary) or having lost functional consumer properties. It is conventionally possible to distinguish biological (bones, food and plant) and synthetic types of waste. All of them may be present in gaseous liquid paste or solid co-operations with varying degrees of danger and toxicity to humans and the environment. Every year, the amount of garbage (about a third of which is packaging) produced by humanity (about 60 million tons) increases by 3\%. Approximately 240 million tons of garbage are generated annually in the United States and the EU, including waste of 1-4 hazard classes.

Analysis shows that substances of hazard class I (mercury, lead, beryllium and its compounds, cadmium and its compounds, hexavalent chromium, arsenic) may be present in the composition of this type of waste. Some types of freons (primarily chlorosubstituted) used in refrigeration and climatic equipment are ozone-depleting [1]. As a result of natural processes of decay or ignition of materials with these substances in landfills, their release into the environment can occur. Insufficient attention to the problem of waste management of electronic and electrical equipment entails serious negative consequences: diseases of people due to environmental degradation associated with pollution of water, soil and air with waste of electronic and electrical equipment [2].

Almost the entire range of solid municipal waste needs to be properly disposed of as soon as possible to avoid causing significant damage to the ecosystem. Both the increasing volume of solid domestic waste on the planet and its disposal are an acute problem of global scale for all countries, requiring the use of increasingly efficient and environmentally sound technologies, taking into account the fact that every year its negative impact on the environment only increases [3-8]. In order to cope with such amounts of solid municipal waste, significant storage areas and modern technologies for their safe storage are required. In addition, all countries of the world are interested in the secondary use of solid municipal waste, including in the form of fuel and electricity. This is the relevance of this study.

Currently, there are about 20 methods of processing solid municipal waste, which, according to the final goal, are divided into liquidation (mainly sanitaryenvironmental) and disposal (involving the use of secondary resources). However, not all of them are highly effective and safe.

The following methods of processing municipal solid waste are mainly used.

1. Landfills at special landfill sites, which receive up to $90 \%$ of the total volume of solid municipal waste.

\footnotetext{
* Corresponding author: Filin.SA@,rea.ru
} 
This method of waste management is most used in the world, including Russia. First, solid municipal waste is taken to special landfills, where it is possible to pre-sort it in different positions. Currently, recycled solid municipal waste can include: waste paper; Relevant obsolete products made of glass, metals, plastic, electrical and electronic municipal appliances, textiles; as well as waste from wood processing and harvesting, autumn foliage, etc. Solid municipal waste, which is not advisable to process, usually refers to irretrievable losses: these heterogeneous solid municipal waste is buried in the upper layer of the earth, after which it is first organic and then inorganic, which make up solid municipal waste for a long period (for example, iron products 10-20 years; car and foil batteries - about 100, car tires - 120-140; plastic bottles, packages and disposable utensils - 180-200; aluminum cans - up to 500 years) spontaneously decompose in natural conditions. Solid municipal waste accumulates extremely quickly and the areas allocated for them increase annually by 250 thousand hectares. Only non-combustible and nontoxic waste is suitable for disposal, which is usually difficult to track. However, during the operation of the landfill, landfill gases are released into the atmosphere, harmful substances (primarily decomposition or melting products of plastic, rubber, etc.) can be released into the environment. In places at the landfill where solid municipal waste is buried, geo-indicators of soils change, which leads to an increase in their filtration ability and, as a result, to contamination of groundwater as a result of natural processes of decomposition of solid municipal waste. All this can cause serious human diseases due to environmental degradation associated with water, soil and air pollution.

Currently, in the UK, Norway and Spain, up to $75 \%$ of all solid municipal waste is buried, in Israel - $80 \%$ (the state with a population of about 9.3 million people generates annually more than 6 million tons of solid waste, including waste of 1-4 hazard classes). For each Russian, there are about 2 thousand tons of untreated waste only at officially registered landfills.

2. Composting is a method of decomposing organic products of only natural origin by microorganisms into a mixture that can be used in growing plants. This recycling method improves soil fertility and allows it to be enriched with useful elements. However, it requires careful preliminary recycling, since the decomposition of waste occurs in a natural way. Glass, metal, plastic, paper are not composted. The resulting biogas also requires cleaning systems for harmful substances.

3. Disposal of solid municipal waste by means of high temperatures. Non-toxic waste is subjected to thermal processing at incinerators. A positive point is the decontamination of landfills, the destruction of any pathogenic microorganisms (harmless ash remains during combustion), a decrease in the initial volumes of waste by about 10 times. Thermal and electrical energy obtained during combustion can be used for lighting and heating of buildings. A significant negative aspect is that this technology does not protect the ecosystem from harmful emissions of combustion products (dioxin, cyanite, furans, etc.: they fall with precipitation, accumulate in the ground, enter the human food chain). Currently, about 40 thousand incinerators operate in the world. In Switzerland, Germany, Denmark and France, about $50 \%$ of all MSW are subject to incineration, in Japan - up to $78 \%$, including 1-4 hazard classes. As a result, a significant amount of harmful combustion products is produced into the atmosphere. In addition, according to the director of the Institute of Ecology of the Higher School of Economics, Doctor of Technical Sciences B. Morgunov, that although the mass remaining after combustion is about $40 \%$ of the initial, its "quality" due to the higher concentration of harmful combustion products in them becomes worse.

4. The technology of plasma processing of solid municipal waste was invented by academician E.P. Velikhov, worked out at the Kurchatov Institute of Atomic Technologies and is a high-temperature type of pyrolysis technology (there is no combustion in a plasma reactor: garbage is not burned, but subjected to gasification), starting at temperatures above $1000{ }^{\circ} \mathrm{C}$ (at such a temperature, in the absence of a combustion process, there are no conditions for the formation of harmful substances - dioxins, furans, nitrogen oxides, sulfur dioxide, carbon dioxide). The process of plasma gasification by electric arc plasma requires maintaining a stable low-temperature plasma $\left(1300-2000{ }^{\circ} \mathrm{C}\right)$. This ensures the complete breakdown of the artificial organic component of solid municipal waste into simple compounds at the molecular level with their incomplete oxidation under the influence of water vapor, air oxygen and waste pressure and avoids the appearance of liquid fractions (resins) in the synthesis gas, which are formed in large quantities at lower temperatures. Also, this temperature of the process ensures the complete destruction of toxic and hardly decomposable components of the waste and, if there are chlorinecontaining components in the waste, allows eliminating the synthesis of secondary especially toxic substances (dioxins). When this temperature is exceeded, the content of nitrogen oxides in the produced synthesis gas and the power consumption for maintaining the plasma charge with a decrease in the life of the plasmatron due to tougher operating conditions increase.

This technology is characterized by a closed process cycle, less due to the formation of a coke residue, ash residue density, allows you to obtain electricity or dispose of residual heat with the possible production of synthesis gas (mixtures of gases whose main components are $\mathrm{CO}, \mathrm{H}_{2}$ and impurities of other combustible gases) by means of multistage purification in accordance with environmental standards of generated flue gases from solid waste products, it allows to split complex polymers into gaseous hydrocarbons and CO. The advantages of this technology: there is no need for a large staff; energy for the plasma plant is generated from recyclable municipal solid waste; allows the disposal of highly toxic waste (toxin emissions are reduced by $99 \%$ ); the resulting pyrolysis composite is safe, used as a construction composite material, can be stored for many years and does not release harmful substances during storage; this is a conditionally alternative energy source. Although synthesis gas is inferior in energy content to 
methane, propane and natural gas in general, its use as a fuel partially replacing coal, fuel oil, natural gas, possibly in steam turbines of power plants, in a diesel generator, in a recovery boiler. A small fraction of natural gas is added to the synthesis gas to stabilize combustion. Synthesis gas can also be used as a raw material for organic synthesis (for the production of methanol and higher alcohols, ammonia, nitrogen fertilizers, synthetic motor oil and fuel through catalysis (it is assumed that in the USA in $10-15$ years $50 \%$ of liquid fuel will be obtained through the processing of solid domestic waste synthesis gas). Synthesis gas can be used to produce steam and electricity both for the own needs of the enterprise and for the population. The efficiency of converting synthesis gas into electricity with large combine-cycle installations is $60 \%$, and usually $40-50 \%$, with $1 \mathrm{~kg}$ of garbage, $1.5-2 \mathrm{~kW}$-hours can be obtained. That is, processing $10 \mathrm{~kg}$ of garbage per day fully provides electricity and heat to one apartment. For small settlements, it is beneficial to build small local plasma waste processing power plants with short transmission lines and minimal heat loss if 1-1.5 tons per hour of solid municipal waste is supplied for processing using plasma technology.

Solid products in the form of non-hydrolyzable (noncombustible) residues and slag from metal oxides and carbonates and silicon (their volume is $5-15 \%$ of the initial mass of solid municipal waste depending on their composition) are also an integral part of the plasma processing process in the form of a black vitreous mass without odor. Disadvantages of this technology: high power consumption, difficulty of cleaning combustion products from heavy metals [9-15].

Radically, the situation with the disposal of solid household waste may change if enterprises for the management of these waste and their processing based on plasma technology are created. The purpose of this study is to propose the organization of a system for recycling solid household and other waste based on plasma technologies for a company under construction with a capacity of about 200 tons of solid household waste per day, depending on their type. The novelty of the study is the justification of the economic feasibility of creating an enterprise for the disposal of solid household and other waste on the basis of the proposed implementation scheme of this technology.

\section{Methodology}

Methods of logical research, methods of management and analysis of organization of solid domestic and other waste disposal system based on plasma technologies, models and algorithms of functioning of this system in the framework of system-information approach are used.

\section{Results and Discussion}

In the vicinity of the city of Karmiel (Israel) in 2010, the Environmental Energy Resources enterprise for the processing of solid municipal waste using a plasmotron manufactured at the Kurchatov Institute of Atomic
Technologies began to operate for the first time. Academician Philip Rutberg in 2011 for the development of plasma technologies was awarded the Global Energy Prize, called the "Nobel energy analogue". According to his project, employees of the Institute of Electrophysics and Electric Power of the Russian Academy of Sciences on the basis of the Skolkovo Science City in 2012 created an experimentalindustrial plant for the disposal of solid waste. This plant consists of a plasmatron (gasifier reactor), a plasma generator with power supply systems, an afterburner, a cooling and purification system, including by steam generation, and exhaust gases. The plasma generator uses an air medium and an AC electric arc with a power of up to $50 \mathrm{~kW}$. Electromagnets are used to stabilize the plasma beam. Lower part of plasmatron is immersed in water bath with formation of hydraulic gate preventing penetration of atmospheric air into plasmatron and mixing of products from the latter with atmosphere. Ash and slag removal device includes grid iron installed in water bath, which slowly rotates around vertical axis. The schematic diagram of the process of solid waste disposal at this plant is given in Fig. 1.

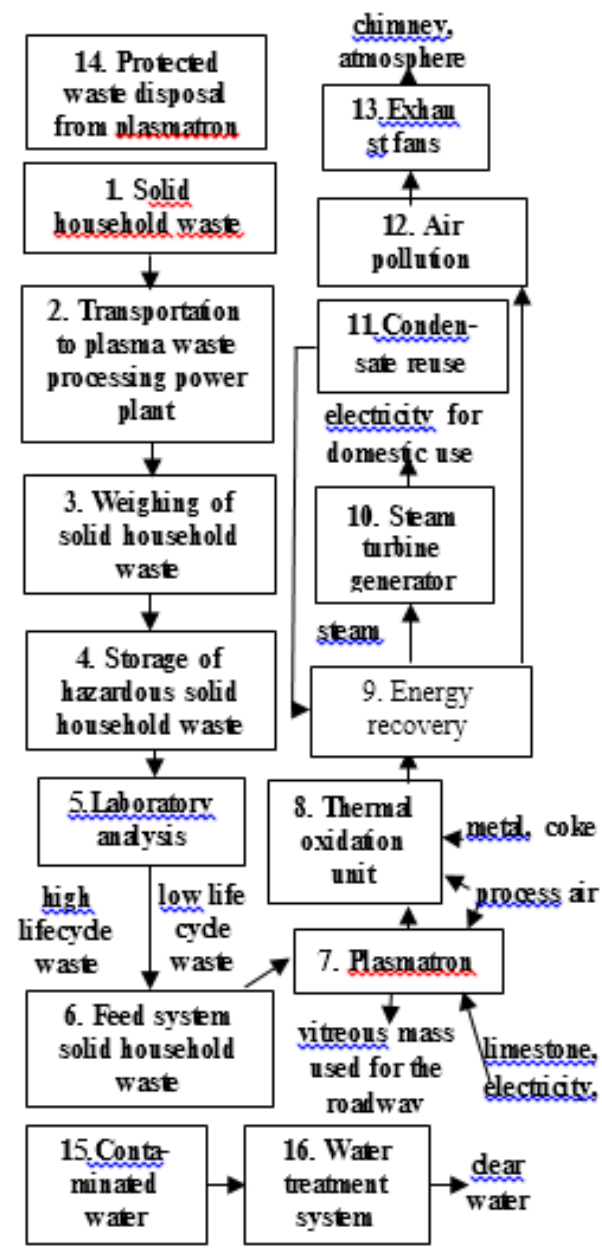

Fig. 1. Schematic diagram of solid waste utilization using plasma technology.

The dried and crushed solid municipal waste is fed by a charging device into a hopper at the top of the plasmatron. Air and water vapor are supplied through the 
tier nozzles, then solid municipal waste is treated with a flow of low-temperature plasma. After the plasmatron is brought to steady state, its operation is maintained by continuous maintenance of the plasma jet, periodic, if necessary, injection of the air-steam mixture, control of the level of solid domestic waste in the plasmatron chamber as they are transformed into synthesis gas and their corresponding periodic batch supply by the loading device. The resulting synthesis gas is continuously pumped from the bottom of the plasmatron.

The resulting synthesis gas can be sent for combustion to a gas boiler house and serve as a partial replacement for natural gas, or to a quincher (evaporative synthesis gas cooler) for its purification. Purified synthesis gas is sent to compressor, then to moisture separator, filter and gas turbine.

For stability of work and increase in power of the power equipment regardless of fluctuations of structure of initial waste the admixture of natural gas is recommended. The gas turbine produces electricity. The gases leaving the turbine enter the waste heat boiler, where steam is generated, and this steam is supplied to the steam turbine, where electricity is also generated. Steam from the steam turbine is returned to the recovery boiler, and flue gases from the latter are discharged through the pipe to the atmosphere. Other synthetic gas schemes are possible.

The hot mineral residue is removed from the plasmatron and enters the bottom of the water bath. In order not to burn the feedstock, it is necessary to control the supply of oxidant-air, so the plasmatron is equipped with several tiers of blow holes for controlling processes by supplying air or steam. From below, the products are captured by a cast iron grate and, when the grate rotates, fall to the bottom of the water tank, where the ash residue cools, neutralizes and is removed.

This pilot plant carried out a series of experiments on plasma gasification of wood, coal, lignite, plastics, refuse derived fuel, automobile tires, etc. (Table 1).
Table 1. Main characteristics of the plant for plasma gasification of wastes.

\begin{tabular}{|c|c|c|c|}
\hline \multirow[b]{2}{*}{ Process parameters } & \multicolumn{3}{|c|}{$\begin{array}{l}\text { Type of waste to be } \\
\text { recycled }\end{array}$} \\
\hline & Wood & $\begin{array}{l}\text { Refuse } \\
\text { derived } \\
\text { fuel }\end{array}$ & $\begin{array}{l}\text { Tyre } \\
\text { waste }\end{array}$ \\
\hline $\begin{array}{l}\text { Heat of raw material } \\
\text { combustion, } \mathrm{MJ} / \mathrm{kg}\end{array}$ & 16 & 15 & 33 \\
\hline Secondary raw material & - & - & $\begin{array}{l}\text { water } \\
\text { vapor }\end{array}$ \\
\hline $\begin{array}{l}\text { Per } 1 \mathrm{~kg} \text { of raw } \\
\text { materials: } \\
\text { plasma-forming gas, } \mathrm{kg} \\
\text { secondary blasting, } \mathrm{kg}\end{array}$ & $\begin{array}{c}1.44 \\
-\end{array}$ & $\begin{array}{c}1.51 \\
-\end{array}$ & $\begin{array}{l}2.88 \\
1.33\end{array}$ \\
\hline $\begin{array}{l}\text { Energy consumption } \\
\mathrm{kw} \cdot \mathrm{h} / \mathrm{kg}\end{array}$ & 1.0 & 1.06 & 1.85 \\
\hline $\begin{array}{l}\text { Plasmatron mode, } \\
\mathrm{MJ} / \mathrm{kg}\end{array}$ & 2.25 & 2.27 & 2.08 \\
\hline Plasma temperature, ${ }^{\circ} \mathbf{C}$ & 1950 & 2000 & 1800 \\
\hline Specific gas exit, $\mathrm{m}^{3} / \mathrm{kg}$ & 2.48 & 2.46 & 5.03 \\
\hline $\begin{array}{l}\text { Heat of gas combustion, } \\
\mathrm{MJ} / \mathrm{m}^{3}\end{array}$ & 6.16 & 5.88 & 5.89 \\
\hline $\begin{array}{l}\text { Gas composition, } \\
\text { volume \%: }\end{array}$ & & & \\
\hline hydrogen $\left(\mathrm{H}_{2}\right)$ & 24.5 & 26.3 & 30.6 \\
\hline carbon monoxide $(\mathrm{CO})$ & 31.4 & 27.5 & 24.0 \\
\hline carbon dioxide $\left(\mathrm{CO}_{2}\right)$ & 3.5 & 3.2 & 5.2 \\
\hline water $\left(\mathrm{H}_{2} \mathrm{O}\right)$ & 4.9 & 4.9 & 4.9 \\
\hline nitrogen $\left(\mathrm{N}_{2}\right)$ & 35.7 & 37.8 & 35.1 \\
\hline
\end{tabular}

Industrial implementation of processing based on this technology of solid municipal waste will require equipment that processes about 200 tons of solid municipal waste per day, depending on their type; room; highly qualified personnel [16]. The existing sample of the working installation of this solid waste processing enterprise covers an area of $3000 \mathrm{~m}^{2}$, the height of the premises should be at least $25 \mathrm{~m}$. Since the dimensions of the premises for this installation complicate the search for premises on the commercial real estate market, the construction of a production building for placing equipment in it is a priority.

Currently, a plant with a production capacity of 20 waste treatment plants per year is being built. Due to the fact that the equipment and technology used are completely new and there are no analogues in the international market, personnel need to be trained to work on it. The training period for new personnel is about 2 months. To work on this equipment, 2 operators and 8 movers are required, of which 4 are responsible for loading raw materials for the equipment and 4 for timely change of tanks for synthesis gas and slag.

The real payback period for most solid waste technologies is estimated at 3-5 years (excluding repayment of interest on loans). The main cost items in the cost of production are energy costs (20-45\%), especially for technologies including grinding and drying operations, equipment maintenance and operation costs, including depreciation charges, especially for energyintensive technologies (up to 40-60\%), which is associated with the high cost of equipment. In some cases (using primary raw materials or high-quality 
secondary raw materials), the cost of raw materials and materials increases from $16-25 \%$ to $40-80 \%$. The wage fund and contributions from it range from $3-8 \%$ to 25 $35 \%$.

The level of taxation has a great influence on the efficiency of solid waste processing technologies. So, the share of two main taxes - VAT and income tax, in the volume of sales of products is estimated at $20-60 \%$, the ratio of the value of taxes to the profit of the enterprise is $85-130 \%$.

The disposal of solid municipal waste using plasma technology in the processing of 1 ton of garbage reduces costs by at least three times compared to any other method of their processing.

To build an enterprise using plasma technology, it is necessary to spend about 900 million rubles. During the analysis of prices for energy and materials, relevant data on prices in the Moscow region were adopted. The analysis showed that, in most cases, products produced from solid municipal waste are uncompetitive (in terms of price) with similar products offered on the market. However, the use of plasma technology is more costeffective than other current technologies for processing solid municipal waste. In particular, this technology significantly reduces the cost of processing 1 ton of solid municipal waste: they are 4 times cheaper than alternative technologies available on the market for processing similar solid municipal waste. When obtaining fuel from solid municipal waste, electricity is spent on maintaining the plasma charge. However, the synthesis gas produced thereby compensates for the energy costs (under ideal reaction conditions) by 4 times. This enterprise can pay off with a certain amount of municipal solid waste processed per year for about 4 years. With an annual processing of 60 thousand tons of solid municipal waste, the plant will make an estimated income: from the processing of solid municipal waste 30 million rubles, from the sale of electricity - 132.5 , from the sale of heat for heating 146.5, from metal smelting 21.4, from glass processing - 20.2 million rubles. In addition to purchasing equipment, annual maintenance, logistics, energy and staff salaries will amount to 53 million rubles.

According to experts, the profit from the sale of products allows you to set those reefs for garbage collection an order of magnitude lower compared to incinerators.

Comparative indicators of application of different methods of processing solid domestic waste are given in Table 2.
Table 2. Comparative indicators of application of different methods of solid waste processing.

\begin{tabular}{|c|l|l|l|}
\hline No. & \multicolumn{1}{|c|}{ Burning } & \multicolumn{1}{|c|}{$\begin{array}{c}\text { Normal } \\
\text { gasification }\end{array}$} & $\begin{array}{c}\text { Plasma } \\
\text { gasification }\end{array}$ \\
\hline 1 & $\begin{array}{l}\text { Destruction } \\
\left.\mathbf{6 5 0}^{\mathbf{}} \mathbf{C}\right)\end{array}$ & $\begin{array}{l}\text { Destruction - } \\
70 \%\left(800^{\mathbf{O}} \mathbf{C}\right)\end{array}$ & $\begin{array}{l}\text { Complete } \\
\text { destruction - } \\
90 \%\end{array}$ \\
\hline 2 & $\begin{array}{l}\text { Dioxins, } \\
\text { resins and } \\
\text { furans are } \\
\text { isolated in } \\
\text { large } \\
\text { quantities }\end{array}$ & $\begin{array}{l}\text { Dioxins, } \\
\text { resins and } \\
\text { furans present }\end{array}$ & $\begin{array}{l}\text { No harmful } \\
\text { substances }\end{array}$ \\
\hline 3 & $\begin{array}{l}\text { Toxic ash - } \\
30 \%\end{array}$ & Ash - 10\% & $\begin{array}{l}\text { Vitreous } \\
\text { inorganic } \\
\text { compound - } \\
5 \%\end{array}$ \\
\hline 4 & Not all waste & Not all waste & Any waste \\
\hline 5 & $\begin{array}{l}\text { Large } \\
\text { volumes }\end{array}$ & $\begin{array}{l}\text { Small } \\
\text { volumes }\end{array}$ & $\begin{array}{l}\text { Large } \\
\text { volumes }\end{array}$ \\
\hline 6 & $\begin{array}{l}\text { High } \\
\text { emission of } \\
\text { gases and fly } \\
\text { ash into the } \\
\text { atmosphere }\end{array}$ & $\begin{array}{l}\text { Average } \\
\text { fraction of } \\
\text { emissions of } \\
\text { gases and fly } \\
\text { ash into the } \\
\text { atmosphere }\end{array}$ & No emissions \\
\hline 7 & $\begin{array}{l}\text { Humidity } \\
\text { sensitivity }\end{array}$ & $\begin{array}{l}\text { Humidity } \\
\text { sensitivity }\end{array}$ & $\begin{array}{l}\text { No sensitivity } \\
\text { to humidity }\end{array}$ \\
\hline
\end{tabular}

As part of the introduction of the best environmental technologies, it is assumed that in Russia 8 plasma waste processing power plants will be built around Moscow, and experimental waste processing power plants will be built in Tatarstan by 2025 . In order to accelerate the introduction of plasma technology for the processing of solid municipal waste, significant support is needed, primarily through investment and the offering of tax incentives with appropriate state control, and public awareness of this form of safe waste management. It is also necessary: a) to constantly analyze new approaches to the disposal of solid municipal waste, calculate the economic efficiency of their implementation and, in case of a positive effect, gradually begin to introduce new technologies, b) invest more quickly in the development and implementation of new Russian high-efficiency technologies and projects for the disposal of solid municipal waste.

Plasma technologies can also be highly effective in new metallurgy, plasma chemistry, medicine and other fields.

\section{Conclusions}

1. As a result of the use of plasma technology for processing solid municipal waste, electricity is eventually generated, environmentally friendly slag, from which activated carbon can be further obtained by certain chemical reactions, and synthesis gas, which can be used as fuel for various kinds of equipment and cars and lighting and heating of premises. An enterprise operating on the basis of this technology will have a closed process cycle with full provision of electricity generated from the processing of solid municipal waste. 
2. The use of plasma technology for the processing of solid municipal waste will, along with a more effective solution to the problem of waste management, can also ensure the production of energy from conditionally renewable sources (the accumulated solid municipal waste at landfills of the world can provide the population with energy for decades, while these waste is constantly replenished). Although the United Kingdom, Israel, India, Canada, China, the Netherlands, the USA and Japan have positive experience in recycling solid municipal waste using plasma technology, Russia has good scientific developments in the field of plasma pyrolysis.

3. Although the application of plasma technologies is most beneficial in the energy sector, when introducing plasma plants and creating solid waste disposal plants using these plants, taking into account the financial benefits in obtaining the raw materials and energy they generate is not the main task, but an additional economic effect. The main thing is to reduce the negative impact of solid municipal waste on the environment and people. And this should become one of the main tasks of the state and society.

\section{References}

1. S.A. Filin, V.E. Rogalin, I.A. Kaplunov, Russian Journal of Applied Chemistry, 91, 10 (2018)

2. I.A. Kalinina, V.V. Maslennikov, S.A. Filin, Ecology of industrial production, 13 (2018)

3. C. Duan, J. Han, S. Zhao, Z. Gao, J. Qiao, G. Yan, Waste Management, 77 (2018)

4. M.I. Boulos, Plasma Chemistry and Plasma Processing, 36, 1 (2016)

5. Z. Shi, H. Du, Z. Li, J. Lu, X. Jiang, Gaoya Dianqi., 53, 4 (2017)

6. A. Bogaerts, A. Berthelot, S. Heijkers, R. Snoeckx, S. Sun, G. Trenchev, K. Van Laer, W. Wang, S. Kolev, Plasma Sources Science and Technology, 26, 6 (2017)

7. K.N.M. Penado, C.L.S. Mahinay, I.B. Culaba, Japanese Journal of Applied Physics, 58, SA (2019)

8. A.L. Suris, Theoretical Foundations of Chemical Engineering, 51, 3 (2017)

9. V.E. Messerle, A.L. Mossé, A.N. Nikonchuk, A.B. Ustimenko, R.V. Baimuldin, Journal of Engineering Physics and Thermophysics, 90, 5 (2017)

10. A. Sanlisoy, M.O. Carpinlioglu, International Journal of Hydrogen Energy, 42, 2 (2017)

11. V.E. Messerle, A.L. Mosse, A.B. Ustimenko, IEEE Transactions on Plasma Science, 44, 12 (2016)

12. N. Indrawan, S. Mohammad, A. Kumar, R.L. Huhnke, Environmental Technology and Innovation, 15 (2019)

13. M.T. Munir, I. Mardon, S. Al-Zuhair, A. Shawabkeh, N.U. Saqib, Renewable and Sustainable Energy Reviews, 116 (2019)
14. A. Ramos, J. Berzosa, J. Espí, F. Clarens, A. Rouboa, Energy Conversion and Management, 209 (2020)

15. R.M. Grigorescu, M.E. Grigore, L Iancu, P. Ghioca, R.-M. Ion, Recycling, 4, 3 (2019)

16. E. Genkin, S. Filin, V. Velikorossov, Z. Kydyrova, K. Anufriyev, E3S Web of Conferences, Series "1st International Conference on Business Technology for a Sustainable Environmental System, BTSES 2020" (2020) 